\title{
Zinc transporters are differentially expressed in human non-small cell lung cancer
}

\author{
Cuiping Huang ${ }^{1,2, *}$, Xiaobo Cui ${ }^{2,3,4,5, *}$, Xiaotian Sun ${ }^{2,3,4,6, *}$, Jingxuan Yang ${ }^{2,3,4}$, \\ Min Li $2,3,4$ \\ ${ }^{1}$ Department of Internal Medicine, College of Clinical Medicine, Hubei University of Science and Technology, Xianning, Hubei \\ 437100, China \\ ${ }^{2}$ The Vivian L. Smith Department of Neurosurgery, the University of Texas Medical School at Houston, Houston, TX 77030, USA \\ ${ }^{3}$ Department of Medicine, The University of Oklahoma Health Sciences Center, Oklahoma City, OK 73104, USA \\ ${ }^{4}$ Department of Surgery, The University of Oklahoma Health Sciences Center, Oklahoma City, OK 73104, USA \\ ${ }^{5}$ Harbin Medical University, Harbin, Heilongjiang 150081, China \\ ${ }^{6}$ Department of Internal Medicine, Clinic of August First Film Studio, Beijing 100161, China \\ *These authors contributed equally to this work
}

Correspondence to: Min Li, email: Min-Li@ouhsc.edu

Keywords: zinc transporter, ZIP4, expression profiling, lung cancer

Received: June 19, 2016

Accepted: August 26, 2016

Published: September 07, 2016

\section{ABSTRACT}

Lung cancer is one of the most common human malignancies worldwide, but its oncogenesis process remains unclear. Recent studies demonstrated that zinc (Zn) and Zn transporters were associated with the development and progression of human cancers. The role of $\mathrm{Zn}$ transporters including ZIPs and ZnTs in lung cancer, however, has never been evaluated. Thus, we aimed to investigate the expression levels of all human $\mathrm{Zn}$ transporters, including 14 ZIPs and $10 \mathrm{ZnTs,}$ in eight different lung cancer cell lines and paired human tumor tissues. We observed great variations in ZIPs and ZnTs mRNA levels across cell lines and human lung cancer specimens. ZIPs showed a tendency to be upregulated, while ZnTs exhibited a downward expression trend. ZIP4 was overexpressed in six lung cancer cell lines and 59\% (26/44) of tumor tissues, which was consistent with results from lung cancer datasets including TCGA database. Our results indicated that the dysregulation of $\mathrm{Zn}$ transporters may contribute to lung tumorigenesis.

\section{INTRODUCTION}

Lung cancer is the most frequently occurring cancer worldwide and the leading cause of cancer-related death in the US, representing almost $14 \%$ of all cancers diagnosed and approximately $28 \%$ of all cancer deaths [1-4]. With a lack of reliable diagnostic markers at early stages of disease and ineffective therapies, the prognosis for lung cancer patients is poor. The 5-year overall survival for lung cancer at all stages is $16.3 \%$; this rate is much lower than that of many other cancers, such as colon (65.2\%), breast $(90.0 \%)$, and prostate $(99.9 \%)$ cancers, the survival rates of which have remained largely unchanged over the last two decades [5]. Despite the extensive research into diagnostic and therapeutic methods for this devastating disease, little is known of the pathogenesis and molecular mechanism of lung cancer. Therefore, identifying new markers and therapeutic targets for the purposes of interrupting infiltrative growth and developing novel treatments for lung cancer is needed.

While many etiological factors participate in the pathogenesis of lung cancer, increasing attention has been paid to the role of trace elements, especially zinc $(\mathrm{Zn})$. $\mathrm{Zn}$ is an essential micronutrient, a metal belonging to the group IIb series, which is associated with the function of over 300 enzymes, thousands of proteins and transcription factors, and upwards of $10 \%$ of the human genome [6-9]. $\mathrm{Zn}$ plays a pivotal role in a series of basic biological processes, such as the metabolism of nucleic acids, proteins, carbohydrates and lipids, and the regulation of gene transcription, cell proliferation, and differentiation [10]. Zn deficiency could impair DNA synthesis, decrease food intake, and induce growth retardation, immune damage, and severe dermatitis $[11,12]$. However, excessive Zn may also exert cytotoxic effects [13]. 
The important role of $\mathrm{Zn}$ in an array of physiological processes necessitates tight control on the intracellular Zn level [14]. Cells have evolved a sophisticated system to maintain $\mathrm{Zn}$ homeostasis. In mammalian cells, two Zn transporter protein families, SLC39A (ZIP, ZRT/ IRT-related protein) and SLC30A (ZnT) [15], serve as regulators of $\mathrm{Zn}$ uptake, efflux, and intracellular compartmentalization. ZIPs may increase cellular $\mathrm{Zn}$ content by taking up $\mathrm{Zn}$ into the cytosol across the plasma membrane, while ZnTs are believed to facilitate the efflux of $\mathrm{Zn}$ from cells or into intracellular organelles, thus decreasing the intracellular Zn level [16]. The ZIP family contains 14 human sequences, while the $\mathrm{ZnT}$ family contains 10 human sequences: these sequences exhibit unique tissue-specific expression and differential responsiveness to various physiologic stimuli [17-19].

$\mathrm{Zn}$ transporter members have recently been implicated in several human malignancies. The cellproliferating effects of labile $\mathrm{Zn}$ and $\mathrm{Zn}$ transporters are tissue-specific. In mammary gland tumor cells, low levels of ZnT1, which lead to a higher concentration of $\mathrm{Zn}$ than that in normal cells, have been detected [20]. The downregulation of ZIP1 and ZIP4 is known to be a potential mechanism for the dramatically diminished $\mathrm{Zn}$ concentrations present in prostate cancer [21]. Conversely, ZIP4 mRNA expression is upregulated by nearly 6 times in human pancreatic cancer; the overexpression of ZIP4 promotes pancreatic cancer growth and metastasis [22-24]. Likewise, ZIP6 and ZIP10 have been correlated with breast cancer metastasis and may play a causal role $[25,26]$. ZIP7, which is located at a critical node in Zn-mediated tyrosine kinase signaling, might be a novel target for cancer treatment [27]. However, few studies have explored the expression of $\mathrm{Zn}$ transporters and their specific roles in lung cancer.

In light of the importance of $\mathrm{Zn}$ and $\mathrm{Zn}$ transporters in the development and progression of human cancers, we investigated whether dysregulated expression of $\mathrm{Zn}$ transporters contributes to lung tumorigenesis. In the present study, we examined the gene profile of $24 \mathrm{Zn}$ transporters (14 ZIPs and $10 \mathrm{ZnTs}$ ) in lung cancer cell lines, normal human lung cells, and non-small cell lung cancer tissue specimens, to further characterize the involvement of $\mathrm{Zn}$ transporters and identify the potential key $\mathrm{Zn}$ transporters that may play important roles in human lung cancer.

\section{RESULTS}

\section{Expression of $\mathrm{Zn}$ transporters in lung cancer cell lines}

We examined the expression levels of all 14 ZIPs and $10 \mathrm{ZnTs}$ mRNA in eight different human lung cancer cell lines, using normal BW1799 cells as controls (Figure 1). ZIP2 was overexpressed in three cell lines (A549, NCI-H661, NCI-H358), while all other ZIPs were overexpressed in at least four cell lines (Figure 1A). Elevated levels of ZIP1, ZIP7, and ZIP10 were found in all eight lung cancer cell lines. The mRNA levels of the 14 ZIPs were all increased in NCI-H358 cells. ZIP4, which was increased by 160 folds in NCI-H358 cells, was the most highly expressed ZIP gene.

Most ZnTs, except ZnT2 and ZnT10, were upregulated in four cell lines. ZnT2 was overexpressed in NCI-H1299 and NCI-H460 cells, while ZnT10 was overexpressed in NCI-H1299 and NCI-H2122 cells (Figure 1B). Two cell lines, NCI-H1299 and NCI-H2122, had relatively high mRNA levels of most ZnTs. Previous studies demonstrated that ZnT6 is predominantly localized in the lung. Our results revealed four cell lines (NCI-H1299, NCI-H2122, NCI-H433, and NCI-H358) with ZnT6 mRNA levels increased by $50 \%$ to $150 \%$.

\section{Expression profile of $\mathrm{Zn}$ transporters in non-small cell lung cancer tissues}

We observed differential overexpression levels of $\mathrm{Zn}$ transporters in the patients of the UT cohort (Figure 2). The mRNAs of six Zn transporters (ZIP1, ZIP6, ZIP7, ZIP9, ZIP11, and ZIP14) were overexpressed in the majority of the patients ( 6 or 7 out of 8 patients, Figure $2 A$ ). The mRNAs of seven Zn transporters (ZIP2, ZIP3, ZIP4, ZIP5, ZIP10, ZIP12, and ZIP13) were overexpressed in at least half of the patients ( 4 or 5 out of 8 patients, Figure $2 \mathrm{~A}$ ). ZIP8 was downregulated in most of the cancer patients except for one patient.

Considering the confirmed role of ZIP4 in the carcinogenesis of pancreatic, liver cancer, and glioblastoma multiform (GBM) [22, 23, 28-30], we further conducted a similar investigation with expanded samples of 36 paired specimens of tumor and surrounding benign tissues from a separate cohorts of patients who had non-small cell lung cancer. We found that $58.3 \%$ $(21 / 36)$ of patients possessed higher ZIP4 mRNA levels in tumor tissues, which were normalized to the matched surrounding non-tumor tissues (Figure 2B). In contrast, $62.5 \%(5 / 8)$ patients in the UT cohort exhibited ZIP4 overexpression. This finding was consistent between these two cohorts $(P=1.00)$. IHC staining also indicated that ZIP4 was overexpressed in tumor tissues (Figure 3).

ZnTs expression was relatively low in most tissue samples (Figure 2C). ZnT5 and ZnT6 were overexpressed in tumor tissues from $75 \%(6 / 8)$ of the patients, while ZnT7 and ZnT9 were overexpressed in tumor tissues from $87.5 \%(7 / 8)$ of the patients. The mRNA levels of all other ZnTs in majority tumor tissues showed a downregulated expression tendency, when compared with those levels in the surrounding non-tumor tissues.

\section{DISCUSSION}

Recent studies have indicated that $\mathrm{Zn}$ transporters and $\mathrm{Zn}$ homeostasis play important roles in malignant 
development and progression, especially in prostate, pancreatic, liver, and breast cancers. The relationship between $\mathrm{Zn}$ transporters and other cancers is a topic of great interest. Until now, little research has focused on $\mathrm{Zn}$ transporters in lung cancer. In the current study, we examined the gene profiles of $\mathrm{Zn}$ transporters in both lung cancer cell lines and human tissue samples. The results demonstrated variations in ZIPs and ZnTs expressions across cell lines and human lung cancer specimens. ZIPs were mostly upregulated, while ZnTs exhibited a downward expression trend. One of the key $\mathrm{Zn}$ transporter ZIP4 is actively expressed and showed upregulation in non-small cell lung cancer. Taken together with the results from our previous studies, our finding of constitutively high levels of ZIP4 mRNA and protein in lung cancer suggests that aberrant activation of the ZIP4 gene may play an important role in tumorigenesis of lung cancer, and shows promise as a potential therapeutic target.

$\mathrm{Zn}$ transporters possess both tissue-specificity and ubiquitous expression patterns within the human body. Such differential expression and subcellular localization suggests that $\mathrm{Zn}$ transporters may exhibit diverse and unique effects on cell biology and physiology. For example, ZnT1 displays a ubiquitous tissue distribution and is more highly expressed in tissues involved in $\mathrm{Zn}$ acquisition, recycling, or transfer, such as the small intestine [31,32], consistent with its function as a major $\mathrm{Zn}$ exporter in the body. ZnT2, ZnT3, ZnT4, and ZnT8 are predominantly expressed in secretory tissues, such as mammary glands, glutamatergic neurons, the prostate, and pancreatic $\beta$-cells [33]. ZnT5, ZnT6, ZnT7, ZnT9, and most ZIPs are widespread and show relatively high expression levels in certain tissues (Table 1), consistent with our previous results [34]. ZnT10 is mainly expressed in brain, retina, and liver tissues [35]. ZIP4 and ZIP5 show a similar pattern of tissue-specific expression, with high expression in the liver, kidney, pancreas, and throughout the small intestine and colon [36]. Multiple studies and tissue array data showed that the greatest amount of ZIP14 is expressed in the liver, followed by the intestine $[37,38]$. In the present study, ZIP4 was also overexpressed in six lung cancer cell lines and in 59\% (26/44) of paired lung cancer and normal tissue specimens, supporting the notion that the ZIP4-induced tumor-promoting effect may participate in lung cancer carcinogenesis.

Early data revealed significantly lower $\mathrm{Zn}$ content and higher $\mathrm{Cu} / \mathrm{Zn}$ ratio in serum from patients with lung cancer than that from patients in serum with

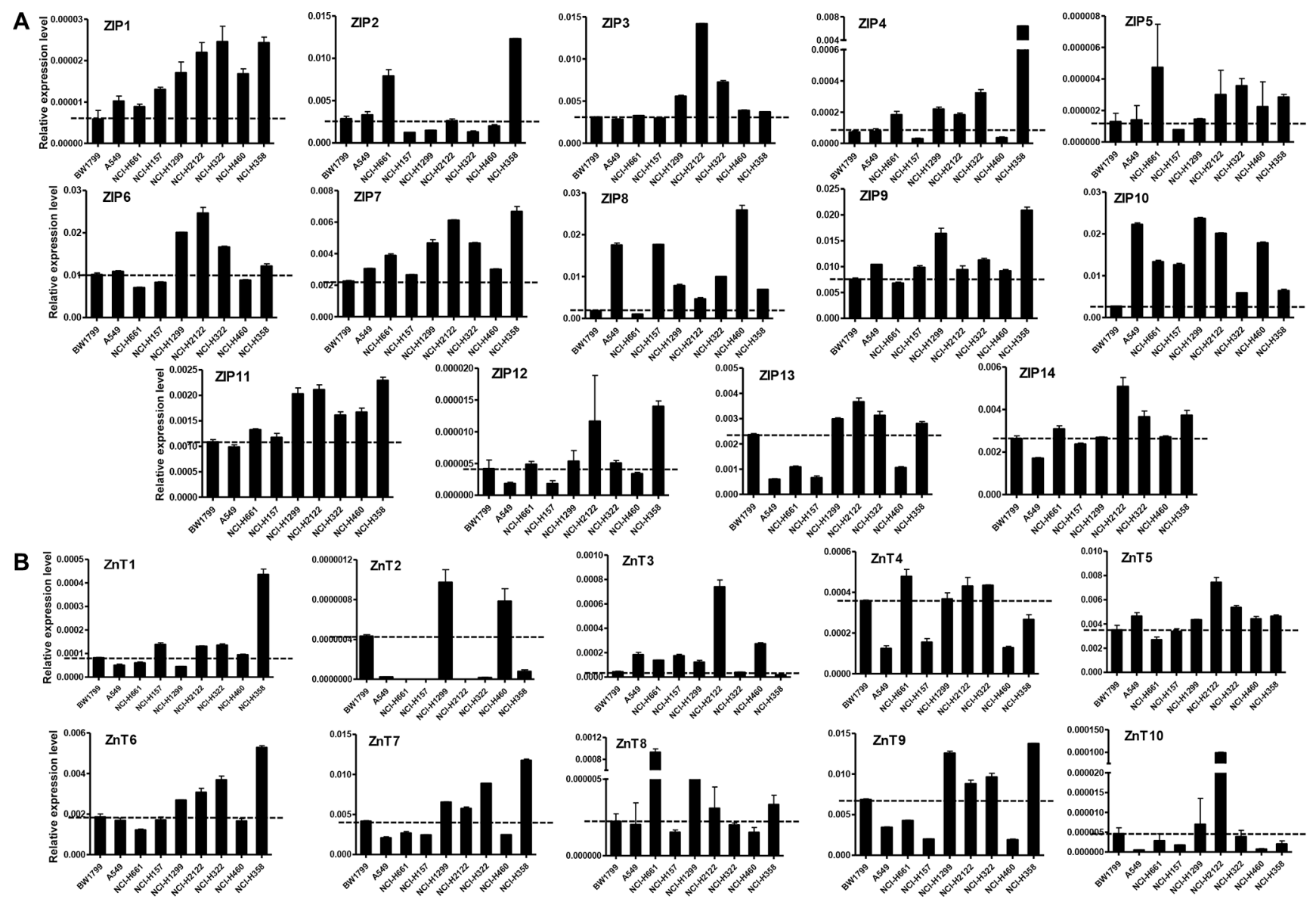

Figure 1: Relative mRNA expression of $\mathrm{Zn}$ transporters in lung cancer cell lines. (A) ZIPs. (B) ZnTs. The relative mRNA expression level was shown in y-axis, which was calculated and normalized to $\beta$-actin. 
nonmalignant lung diseases or normal healthy controls. Progressive changes were observed with advanced stages of disease and postoperative survival of lung malignancy [39-41]. Later studies demonstrated that dietary $\mathrm{Zn}$ intake was associated with a lower risk of lung cancer [42-45]. However, no research has focused on the significance of $\mathrm{Zn}$ and $\mathrm{Zn}$ transporters in lung tumorigenesis, even though there are considerable data indicating that $\mathrm{Zn}$ transporters play definite tumorpromoting roles in many cancers.

To date, ZIP4 is the only mammalian SLC39A superfamily member that has been shown to be an essential zinc transporter and is involved in the adaptation to $\mathrm{Zn}$ deficiency [30]. Consequently, ZIP4 may also mediate carcinogenesis. This hypothesis was confirmed in prostate cancer [46], pancreatic cancer [22-24, 34, 47, 48], and
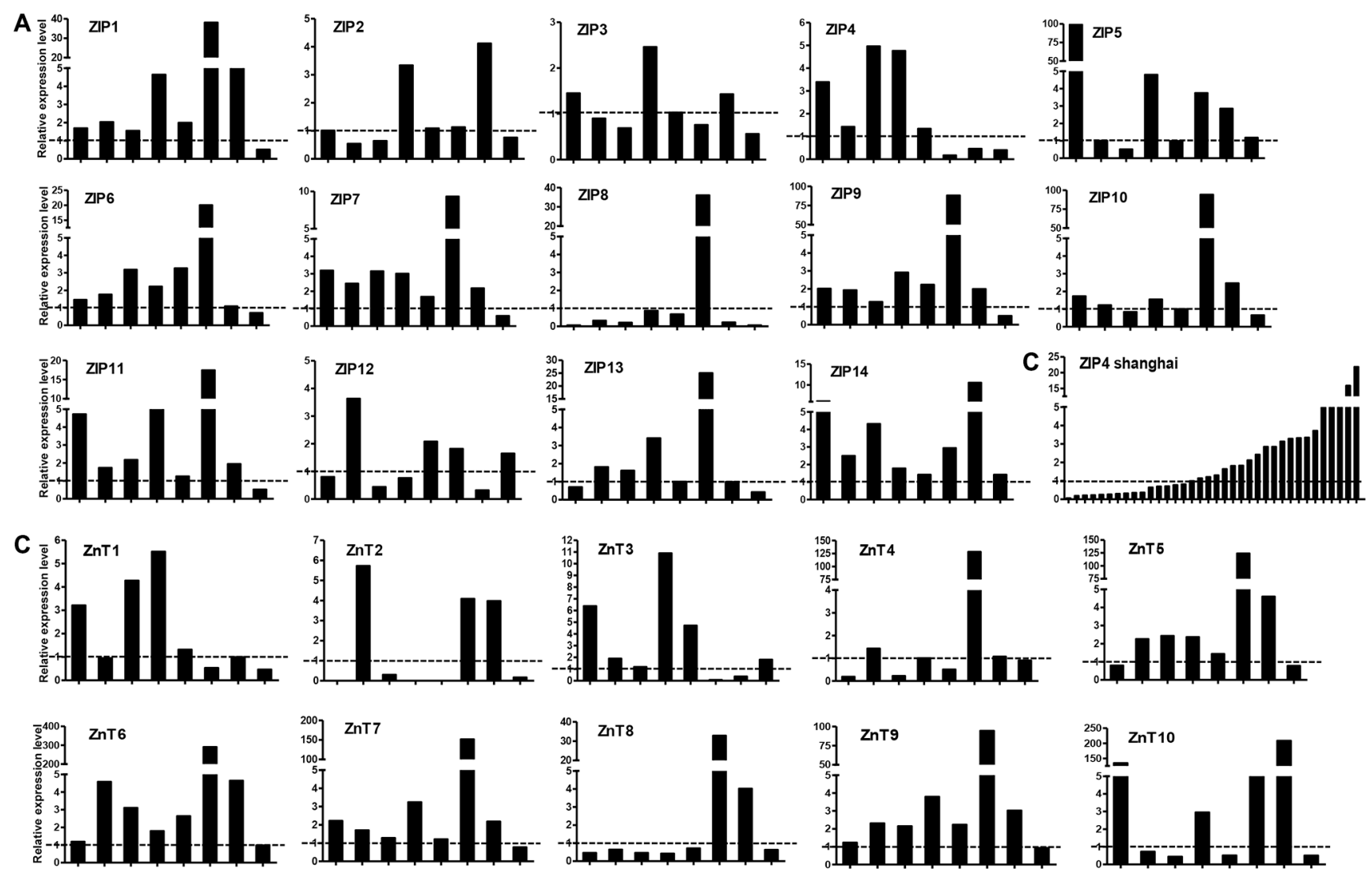

Figure 2: Relative mRNA expression of Zn transporters in lung cancer tissues. (A) ZIPs in the UT Health cohort. (B) ZIP4 in the Shanghai cohort. (C) ZnTs in the UT Health cohort. Y-axis indicated fold change of gene expression (tumor versus non-tumor). X-axis indicated each lung cancer tissue samples. The relative expression was calculated and normalized to $\beta$-actin.
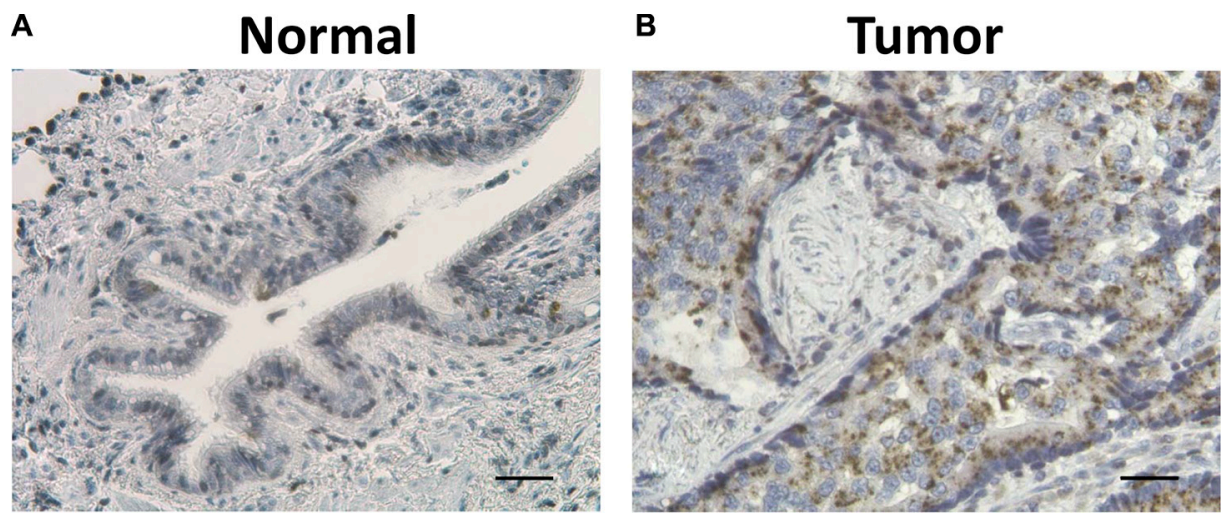

Figure 3: Representative hematoxylin (HE) and ZIP4 IHC staining in surrounding normal tissues (A) and lung cancer tissues (B). Tissue sections were stained using ZIP4-specific Ab. The brown color indicates positive ZIP4 staining with the cell nuclei stained blue by haemotoxylin. Scale bar represents $100 \mu \mathrm{m}$. 
Table 1: Summary of the $\mathrm{Zn}$ transporter family members

\begin{tabular}{|c|c|c|c|c|}
\hline Gene name & Alias & Tissue/cell distribution & Subcellular localization & Clinical significance \\
\hline SLC30A1 & ZnT1 & Widespread & Plasma membrane & $\begin{array}{l}\text { Associated with embryonic } \\
\text { death [32] }\end{array}$ \\
\hline SLC30A2 & $\mathrm{ZnT} 2$ & $\begin{array}{l}\text { Mammary gland, prostate, } \\
\text { retina, pancreas, small } \\
\text { intestine, and kidney }\end{array}$ & $\begin{array}{l}\text { Endosomal/ lysosomal/ } \\
\text { secretory vesicles, } \\
\text { plasma membrane, and } \\
\text { mitochondria }\end{array}$ & $\begin{array}{l}\text { Reduce zinc content in } \\
\text { nursing women [31] }\end{array}$ \\
\hline SLC30A3 & $\mathrm{ZnT3}$ & Brain, testes, and pancreas & Synaptic vesicle & $\begin{array}{l}\text { Seizures, learning deficits, } \\
\text { and memory loss [18] }\end{array}$ \\
\hline SLC30A4 & ZnT4 & $\begin{array}{l}\text { Widespread, predominant in } \\
\text { mammary gland, placenta, } \\
\text { prostate, brain, and kidney }\end{array}$ & $\begin{array}{l}\text { Endosomal/ secretory } \\
\text { vesicles, and plasma } \\
\text { membrane }\end{array}$ & Lethal milk [31] \\
\hline SLC30A5 & ZnT5 & $\begin{array}{l}\text { Widespread, predominant } \\
\text { in heart, placenta, pancreas, } \\
\text { prostate, ovary, testis, small } \\
\text { intestine, thymus, and bone }\end{array}$ & $\begin{array}{l}\text { Golgi, unknown vesicles, } \\
\text { and plasma membrane }\end{array}$ & $\begin{array}{l}\text { Bone abnormalities and } \\
\text { heart failure }[16]\end{array}$ \\
\hline SLC30A6 & ZnT6 & $\begin{array}{l}\text { Widespread, predominant in } \\
\text { brain, lung, and intestine }\end{array}$ & $\begin{array}{l}\text { Golgi, and unknown } \\
\text { vesicles }\end{array}$ & Alzheimer's disease [13] \\
\hline SLC30A7 & $\mathrm{ZnT7}$ & $\begin{array}{l}\text { Widespread, predominant in } \\
\text { intestine, stomach, prostate, } \\
\text { retina, pancreas, testis, and } \\
\text { muscle }\end{array}$ & $\begin{array}{l}\text { Golgi, and unknown } \\
\text { vesicles }\end{array}$ & $\begin{array}{l}\text { Prostate cancer, low } \\
\text { adiposity, and diet-induced } \\
\text { diabetes [17] }\end{array}$ \\
\hline SLC30A8 & $\mathrm{ZnT} 8$ & $\begin{array}{l}\text { Pancreas, thyroid, adrenal } \\
\text { gland, and testis }\end{array}$ & Secretory granule & Diabetes [19] \\
\hline SLC30A9 & ZnT9 & Widespread & Cytoplasm, nucleus & Lower in obese women [33] \\
\hline SLC30A10 & $\mathrm{ZnT} 10$ & Brain, retina, and liver & Unknown & $\begin{array}{l}\text { Contribute to the } \\
\text { progression of Alzheimer's } \\
\text { disease }[14]\end{array}$ \\
\hline SLC39A1 & ZIP1/ ZIRTL & Widespread & $\begin{array}{l}\text { Plasma membrane and } \\
\text { intracellular vesicles }\end{array}$ & $\begin{array}{l}\text { Prostate cancer and } \\
\text { neurodegeneration }[11]\end{array}$ \\
\hline SLC39A2 & ZIP2/ Eti-1/ 6A1 & Widespread & Plasma membrane & $\begin{array}{l}\text { Involved in keratinocyte } \\
\text { differentiation [18] }\end{array}$ \\
\hline SLC39A3 & ZIP3 & $\begin{array}{l}\text { Widespread, mammary } \\
\text { cells, and testis }\end{array}$ & $\begin{array}{l}\text { Plasma membrane and } \\
\text { lysosomes }\end{array}$ & Neurodegeneration [31] \\
\hline SLC39A4 & ZIP4 & $\begin{array}{l}\text { Gastrointestinal tract, } \\
\text { kidney, and hippocampal } \\
\text { neurons }\end{array}$ & $\begin{array}{l}\text { Plasma membrane, } \\
\text { lysosomes, and apical } \\
\text { surface of enterocytes }\end{array}$ & $\begin{array}{l}\text { Acrodermatitis } \\
\text { enteropathica, pancreatic } \\
\text { cancer, and liver cancer } \\
{[22,30]}\end{array}$ \\
\hline SLC39A5 & ZIP5/ LZT-Hs7 & $\begin{array}{l}\text { Pancreas, kidney, liver, } \\
\text { stomach, and intestine }\end{array}$ & $\begin{array}{l}\text { Plasma membrane, } \\
\text { lysosomes, and } \\
\text { basolateral surface of } \\
\text { enterocytes }\end{array}$ & Alcoholic liver disease [16] \\
\hline SLC39A6 & ZIP6/ LIV1 & Widespread & Plasma membrane & $\begin{array}{l}\text { Breast, pancreatic, cervical } \\
\text { and prostate cancers, and } \\
\text { neuroblastoma }\end{array}$ \\
\hline SLC39A7 & ZIP7/ HKE4 & Widespread & $\begin{array}{l}\text { ER, Golgi, and } \\
\text { intracellular vesicles }\end{array}$ & Breast cancer [27] \\
\hline SLC39A8 & $\begin{array}{l}\text { ZIP8/ BIGM103/ } \\
\text { LZT-Hs6 }\end{array}$ & $\begin{array}{l}\text { Widespread, predominant in } \\
\mathrm{T} \text { cells, erythroid, and testis }\end{array}$ & $\begin{array}{l}\text { Plasma membrane, } \\
\text { lysosomes, and } \\
\text { mitochondria }\end{array}$ & $\begin{array}{l}\text { Inflammation, breast cancer, } \\
\text { and cadmium-mediated } \\
\text { toxicity }[16]\end{array}$ \\
\hline
\end{tabular}




\begin{tabular}{|c|c|c|c|c|}
\hline SLC39A9 & ZIP9 & Widespread & Trans-Golgi & $\begin{array}{l}\text { Prostate cancer and breast } \\
\text { cancer }\end{array}$ \\
\hline SLC39A10 & ZIP10/ LZT-Hs2 & $\begin{array}{l}\text { Brain, liver, erythroid, and } \\
\text { kidney }\end{array}$ & Plasma membrane & Breast cancer [26] \\
\hline SLC39A11 & ZIP11 & Testis and digestive system & Cytoplasm and nuclei & $\begin{array}{l}\text { Help maintain mucosal } \\
\text { integrity and function [31] }\end{array}$ \\
\hline SLC39A12 & ZIP12 & $\begin{array}{l}\text { Brain, lung, testis, and } \\
\text { retina }\end{array}$ & Unknown & $\begin{array}{l}\text { Essential for neurulation and } \\
\text { neuronal differentiation [31] }\end{array}$ \\
\hline SLC39A13 & ZIP13 & Widespread & $\begin{array}{l}\text { Intracellular vesicles and } \\
\text { Golgi }\end{array}$ & $\begin{array}{l}\text { Ehlers-Danlos } \\
\text { syndrome (SCD-EDS) [18] }\end{array}$ \\
\hline SLC39A14 & ZIP14 & Widespread & Plasma membrane & $\begin{array}{l}\text { Asthma, inflammation, and } \\
\text { colorectal cancer [38] }\end{array}$ \\
\hline
\end{tabular}

Table 2: Lung cancer datasets showing increased ZIP4 expression

\begin{tabular}{llcccccc}
\hline \multicolumn{1}{c}{ Dataset } & \multicolumn{1}{c}{ Tumor type } & Case & Sample type & Fold change & $\boldsymbol{P}$ value & Journal & Year \\
\hline Su [50] & Adenocarcinoma & 318 & mRNA & 2.448 & $2.15 \mathrm{E}-6$ & BMC Genomics & 2007 \\
Hou [51] & Adenocarcinoma & 780 & mRNA & 2.134 & $4.94 \mathrm{E}-10$ & PLoS one & 2010 \\
Landi [52] & Adenocarcinoma & 132 & mRNA & 1.761 & $2.75 \mathrm{E}-18$ & PLoS one & 2008 \\
Bittner & $\begin{array}{l}\text { Non-small cell lung } \\
\text { carcinoma }\end{array}$ & 1142 & mRNA & 1.364 & 0.011 & No & 2012 \\
TCGA & Adenocarcinoma & 1325 & mRNA & 1.158 & $1.73 \mathrm{E}-14$ & No & 2012 \\
\hline
\end{tabular}

hepatocellular carcinoma [30]. This concept is also supported by the results from a meta-analysis of microarray data deposited in the Oncomine and Geo databases for ZIP4 (SLC39A4) expression. In the Oncomine database, ZIP4 was found to be among the top $10 \%$ of genes expressed in many human cancers and was associated with an advanced tumor stage. In the Geo database, ample data on SLC39A4 suggested that elevated ZIP4 mRNA was found in lymphoma, melanoma, and metastatic colon cancer. Meanwhile, the TCGA database also indicated that higher ZIP4 mRNA expression was associated with poorly differentiated lung cancer, lower probability of survival, and shorter overall survival; while lower ZIP4 mRNA expression was predictive for well-differentiated lung cancer, higher probability of survival, and longer overall survival. However, few studies have investigated the functional relevance between $\mathrm{Zn}$ transporters and lung cancer. Table 2 displays the information regarding ZIP4 expression in lung cancer from different databases. In the present study, our results showed that the differential expression of ZIP4 level may serve as a biomarker for lung cancer. However, the ZIP4-related molecular mechanism should be thoroughly examined.

In summary, our study described a complete gene profiling of $\mathrm{Zn}$ transporters (14 ZIPs and $10 \mathrm{ZnTs}$ ) in human lung cancer tissues and cell lines. The expression of $\mathrm{Zn}$ transporters, particularly ZIP4, was dysregulated in non-small cell lung cancer. These findings may provide new insight into understanding the lung cancer pathogenesis and developing new targeted therapies. Further studies of the underlying biologic mechanisms of the aberrantly expressed ZIP4 and Zn transporters in lung cancer are warranted.

\section{MATERIALS AND METHODS}

\section{Chemicals and reagents}

The iQ SYBR Green supermix and iScript cDNA synthesis kits were purchased from Bio-Rad (Hercules, CA). The RNAqueous-4PCR and DNA removal kits were obtained from Ambion (Austin, TX). The avidin-biotin reaction $(\mathrm{ABC})$ kit was ordered from Vector Laboratories (Burlingham, CA). Other chemicals were purchased from Sigma (St. Louis, MO).

\section{Cell culture and tissue collection}

Human lung cancer cell lines A549, H460, H1299, H2122, H661, H157, H322, and H358 were purchased from the American Type Culture Collection (ATCC, Rockville, MD). All cells were maintained in RPMI 1640 containing $10 \%$ fetal bovine serum (FBS), $100 \mathrm{U} / \mathrm{mL}$ penicillin, 100 $\mathrm{U} / \mathrm{mL}$ streptomycin, and $2 \mathrm{mM}$ glutamine in a humidified atmosphere with $5 \% \mathrm{CO}_{2}$ at $37^{\circ} \mathrm{C}$. BW1799 normal human lung cells were kindly provided by Dr. Xiangwei Wu of the University of Texas MD Anderson Cancer Center and were maintained in Keratinocyte-SFM 
medium. Two independent cohorts of lung tumor tissues and surrounding non-tumor tissues were collected from patients pathologically diagnosed with non-small cell lung cancer who underwent surgery at the University of Texas Health Science Center at Houston (UTHealth cohort, $n=8$ ) and Fudan University Shanghai Cancer Center (Shanghai cohort, $n=36$ ), respectively. Informed consent was obtained from each patient. All experiments were performed in accordance with the Declaration of Helsinki and approved guidelines.

\section{RNA Extraction and real-time PCR (RT-PCR)}

Total RNA was extracted from the cell lines and homogenized lung tissues using an Ambion "RNAqueous4PCR" kit in accordance with the manufacturer's instructions. Briefly, cells or tissue samples were lysed with Ambion lysis solution for $20 \mathrm{~min}$. The lysates were mixed with an equal volume of $64 \%$ ethanol, and were then transferred to an Ambion mini-column in a 2-ml collection tube and centrifuged at $10,000 \times \mathrm{g}$ for $1 \mathrm{~min}$. The column was washed in turn with $700 \mu$ l of wash buffer 1,500 $\mu$ l of wash buffer 2, and $500 \mu$ l of wash buffer 3 . After incubation with $50 \mu 1$ of prewarmed elution solution, the eluted fluid was collected using a new tube and recovered. We added another $50 \mu \mathrm{l}$ of elution solution, followed by centrifugation at $10,000 \times \mathrm{g}$ for $1 \mathrm{~min}$ at room temperature. The extracted RNA was treated with DNase I to remove genomic DNA contamination using an Ambion DNA removing kit (Austin, Texas). Then, the extracted RNA was quantified by measuring absorbance $(260 \mathrm{~nm})$. The mRNA levels for ZIPs and ZnTs in lung cancer cells and tissues were analyzed via RT-PCR using the iCycler system (Bio-Rad, Hercules, CA) with the same primer sequences as described previously [30]. The RT-PCR reaction system included $100 \mathrm{nM}$ of each primer, diluted cDNA templates, and iQ SYBR Green supermix, and was performed by running for 40 cycles at $95^{\circ} \mathrm{C}$ for $20 \mathrm{sec}$ and $60^{\circ} \mathrm{C}$ for $1 \mathrm{~min}$. RT-PCR efficiency was evaluated by serially diluting the template cDNA and collecting the melting curve data to assess RT-PCR specificity. All sample measurements were run in triplicate. The corresponding no-reverse transcriptase (RT) mRNA sample was included as a negative control. The $\beta$-actin primer was included in every plate to correct for sampleto-sample variation. The mRNA level of each sample for each gene was normalized to that of the $\beta$-actin mRNA. The relative mRNA level was presented as $2^{\wedge}[(\mathrm{Ct} / \beta$-actin - Ct/gene of interest)].

\section{Immunohistochemical (IHC) staining}

Clinical lung cancer specimens and matched adjacent non-tumor tissue specimens were collected and processed into 5- $\mu \mathrm{m}$ slices using a Cryostat (Meyer Instruments, Houston, TX). Tissue slices were incubated with homemade anti-hZIP4 antibody for $1 \mathrm{~h}$ at room temperature after blocking buffer was added for $30 \mathrm{~min}$ at room temperature. The human ZIP4 antibody was generated in rabbits against a KLH-conjugated 14-amino acid synthetic peptide as previously described [49]. After washing with PBS, the slices were incubated with biotinylated secondary antibody for $30 \mathrm{~min}$, and then avidin-biotin-peroxidase solution (ABC) for $1 \mathrm{~h}$ at room temperature, followed by $0.1 \% \mathrm{DAB}$ and $0.003 \% \mathrm{H}_{2} \mathrm{O}_{2}$ in Tris-buffered saline for 5-10 min. Immune complexes were detected under a phase contrast microscope.

\section{Statistical analysis}

Quantitative data are shown as means \pm standard deviations. Significant differences between control and treatment groups were determined using independent Student's $t$-test. The data were analyzed using SPSS software 17.0. A $P$ value of $<0.05$ was considered statistically significant.

\section{CONFLICTS OF INTEREST}

The authors declare no conflicts of interest.

\section{GRANT SUPPORT}

This work was supported in part by the William and Ella Owens Medical Research Foundation, and the MacDonald Research Fund.

\section{Authors' contributions}

C.H. and X.C: Performance of experiments, data analysis, and manuscript writing. X.S.: Data interpretation and manuscript writing. J.Y.: Collection of human tissues and manuscript revision. M.L.: Conception, design, and paper revision. All of the authors reviewed and approved the manuscript.

\section{REFERENCES}

1. Jemal A, Bray F, Center MM, Ferlay J, Ward E, Forman D. Global cancer statistics. CA Cancer J Clin. 2011; 61:69-90.

2. Youlden DR, Cramb SM, Baade PD. The International Epidemiology of Lung Cancer: geographical distribution and secular trends. J Thorac Oncol. 2008; 3:819-31.

3. Cagle PT, Dacic S. Lung cancer and the future of pathology. Arch Pathol Lab Med. 2011; 135:293-5.

4. Neal JW, Gubens MA, Wakelee HA. Current management of small cell lung cancer. Clin Chest Med. 2011; 32:853-63.

5. Siegel R, Naishadham D, Jemal A. Cancer statistics for Hispanics/Latinos, 2012. CA Cancer J Clin. 2012; 62:283-98. 
6. Tupler R, Perini G, Green MR. Expressing the human genome. Nature. 2001; 409:832-3.

7. Ho E, Ames BN. Low intracellular zinc induces oxidative DNA damage, disrupts p53, NFkappa B, and AP1 DNA binding, and affects DNA repair in a rat glioma cell line. Proc Natl Acad Sci USA. 2002; 99:16770-5.

8. Andreini C, Banci L, Bertini I, Rosato A. Counting the zincproteins encoded in the human genome. J Proteome Res. 2006; 5:196-201

9. Mao X, Kim BE, Wang F, Eide DJ, Petris MJ. A histidinerich cluster mediates the ubiquitination and degradation of the human zinc transporter, hZIP4, and protects against zinc cytotoxicity. J Biol Chem. 2007; 282:6992-7000.

10. Vallee BL, Falchuk KH. The biochemical basis of zinc physiology. Physiological reviews. 1993; 73:79-118.

11. Berg JM, Shi Y. The galvanization of biology: a growing appreciation for the roles of zinc. Science. 1996; 271:1081-5.

12. Prasad AS. Zinc in human health: effect of zinc on immune cells. Mol Med. 2008; 14:353-7.

13. Murakami M, Hirano T. Intracellular zinc homeostasis and zinc signaling. Cancer science. 2008; 99:1515-22.

14. Sekler I, Sensi SL, Hershfinkel M, Silverman WF. Mechanism and regulation of cellular zinc transport. Mol Med. 2007; 13:337-43.

15. Lichten LA, Cousins RJ. Mammalian zinc transporters: nutritional and physiologic regulation. Annu Rev Nutr. 2009; 29:153-76.

16. Gaither LA, Eide DJ. Eukaryotic zinc transporters and their regulation. Biometals. 2001; 14:251-70.

17. Kambe T, Yamaguchi-Iwai Y, Sasaki R, Nagao M. Overview of mammalian zinc transporters. Cellular and molecular life sciences. 2004; 61:49-68.

18. Eide DJ. Zinc transporters and the cellular trafficking of zinc. Biochimica et biophysica acta. 2006; 1763:711-22.

19. Cousins RJ, Liuzzi JP, Lichten LA. Mammalian zinc transport, trafficking, and signals. J Biol Chem. 2006; 281:24085-9.

20. Lee R, Woo W, Wu B, Kummer A, Duminy H, Xu Z. Zinc accumulation in N-methyl-N-nitrosourea-induced rat mammary tumors is accompanied by an altered expression of ZnT-1 and metallothionein. Exp Biol Med (Maywood). 2003; 228:689-96.

21. Huang L, Kirschke CP, Zhang Y. Decreased intracellular zinc in human tumorigenic prostate epithelial cells: a possible role in prostate cancer progression. Cancer Cell Int. 2006; 6:10.

22. Li M, Zhang Y, Liu Z, Bharadwaj U, Wang H, Wang X, Zhang S, Liuzzi JP, Chang SM, Cousins RJ, Fisher WE, Brunicardi FC, Logsdon CD, et al. Aberrant expression of zinc transporter ZIP4 (SLC39A4) significantly contributes to human pancreatic cancer pathogenesis and progression. Proc Natl Acad Sci USA. 2007; 104:18636-41.

23. Li M, Zhang Y, Bharadwaj U, Zhai QJ, Ahern $\mathrm{CH}$, Fisher WE, Brunicardi FC, Logsdon CD, Chen C, Yao Q. Down-regulation of ZIP4 by RNA interference inhibits pancreatic cancer growth and increases the survival of nude mice with pancreatic cancer xenografts. Clin Cancer Res. 2009; 15:5993-6001.

24. Logsdon CD, Simeone DM, Binkley C, Arumugam T, Greenson JK, Giordano TJ, Misek DE, Kuick R, Hanash S. Molecular profiling of pancreatic adenocarcinoma and chronic pancreatitis identifies multiple genes differentially regulated in pancreatic cancer. Cancer Res. 2003; 63:2649-57.

25. Grattan BJ, Freake HC. Zinc and cancer: implications for LIV-1 in breast cancer. Nutrients. 2012; 4:648-75.

26. Kagara N, Tanaka N, Noguchi S, Hirano T. Zinc and its transporter ZIP10 are involved in invasive behavior of breast cancer cells. Cancer science. 2007; 98:692-7.

27. Hogstrand C, Kille P, Nicholson RI, Taylor KM. Zinc transporters and cancer: a potential role for ZIP7 as a hub for tyrosine kinase activation. Trends Mol Med. 2009; 15:101-11.

28. Zhang Y, Yang J, Cui X, Chen Y, Zhu VF, Hagan JP, Wang H, Yu X, Hodges SE, Fang J, Chiao PJ, Logsdon CD, Fisher WE, et al. A novel epigenetic CREB-miR-373 axis mediates ZIP4-induced pancreatic cancer growth. EMBO Mol Med. 2013; 5:1322-34.

29. Lin Y, Chen Y, Wang Y, Yang J, Zhu VF, Liu Y, Cui X, Chen L, Yan W, Jiang T, Hergenroeder GW, Fletcher SA, Levine JM, et al. ZIP4 is a novel molecular marker for glioma. Neuro Oncol. 2013; 15:1008-16.

30. Weaver BP, Zhang Y, Hiscox S, Guo GL, Apte U, Taylor KM, Sheline CT, Wang L, Andrews GK. Zip4 (Slc39a4) expression is activated in hepatocellular carcinomas and functions to repress apoptosis, enhance cell cycle and increase migration. PLoS One. 2010; 5.

31. Liuzzi JP, Cousins RJ. Mammalian zinc transporters. Annu Rev Nutr. 2004; 24:151-72.

32. McMahon RJ, Cousins RJ. Regulation of the zinc transporter ZnT-1 by dietary zinc. Proc Natl Acad Sci USA. 1998; 95:4841-6.

33. Kelleher SL, Lonnerdal B. Zn transporter levels and localization change throughout lactation in rat mammary gland and are regulated by $\mathrm{Zn}$ in mammary cells. J Nutr. 2003; 133:3378-85.

34. Yang J, Zhang Y, Cui X, Yao W, Yu X, Cen P, Hodges SE, Fisher WE, Brunicardi FC, Chen C, Yao Q, Li M. Gene Profile Identifies Zinc Transporters Differentially Expressed in Normal Human Organs and Human Pancreatic Cancer. Current Molecular Medicine. 2013; 13:401-409.

35. Seve M, Chimienti F, Devergnas S, Favier A. In silico identification and expression of SLC30 family genes: an expressed sequence tag data mining strategy for the characterization of zinc transporters' tissue expression. BMC genomics. 2004; 5:32.

36. Wang F, Kim BE, Dufner-Beattie J, Petris MJ, Andrews G, Eide DJ. Acrodermatitis enteropathica mutations affect transport activity, localization and zinc-responsive 
trafficking of the mouse ZIP4 zinc transporter. Hum Mol Genet. 2004; 13:563-71.

37. Tominaga K, Kagata T, Johmura Y, Hishida T, Nishizuka M, Imagawa M. SLC39A14, a LZT protein, is induced in adipogenesis and transports zinc. FEBS J. 2005; 272:1590-9.

38. Liuzzi JP, Lichten LA, Rivera S, Blanchard RK, Aydemir TB, Knutson MD, Ganz T, Cousins RJ. Interleukin-6 regulates the zinc transporter Zip14 in liver and contributes to the hypozincemia of the acute-phase response. Proc Natl Acad Sci USA. 2005; 102:6843-8.

39. Diez M, Cerdan FJ, Arroyo M, Balibrea JL. Use of the copper/zinc ratio in the diagnosis of lung cancer. Cancer. 1989; 63:726-30.

40. Ferrigno D, Buccheri G, Camilla T. Serum copper and zinc content in non-small cell lung cancer: abnormalities and clinical correlates. Monaldi Arch Chest Dis. 1999; 54:204-8.

41. Oyama T, Matsuno K, Kawamoto T, Mitsudomi T, Shirakusa T, Kodama Y. Efficiency of serum copper/zinc ratio for differential diagnosis of patients with and without lung cancer. Biological trace element research. 1994; 42:115-27.

42. Zhou W, Park S, Liu G, Miller DP, Wang LI, Pothier L, Wain JC, Lynch TJ, Giovannucci E, Christiani DC. Dietary iron, zinc, and calcium and the risk of lung cancer. Epidemiology. 2005; 16:772-9.

43. Mahabir S, Spitz MR, Barrera SL, Beaver SH, Etzel C, Forman MR. Dietary zinc, copper and selenium, and risk of lung cancer. Int J Cancer. 2007; 120:1108-15.

44. Lee DH, Jacobs DR, Jr. Interaction among heme iron, zinc, and supplemental vitamin $\mathrm{C}$ intake on the risk of lung cancer: Iowa Women's Health Study. Nutr Cancer. 2005; 52:130-7.

45. Mahabir S, Forman MR, Barerra SL, Dong YQ, Spitz MR, Wei Q. Joint effects of dietary trace metals and DNA repair capacity in lung cancer risk. Cancer Epidemiol Biomarkers Prev. 2007; 16:2756-62.
46. Chen QG, Zhang Z, Yang Q, Shan GY, Yu XY, Kong CZ. The role of zinc transporter ZIP4 in prostate carcinoma. Urologic oncology. 2012; 30:906-11.

47. Zhang Y, Bharadwaj U, Logsdon CD, Chen C, Yao Q, Li M. ZIP4 regulates pancreatic cancer cell growth by activating IL-6/STAT3 pathway through zinc finger transcription factor CREB. Clin Cancer Res. 2010; 16:1423-30.

48. Zhang Y, Chen C, Yao Q, Li M. ZIP4 upregulates the expression of neuropilin-1, vascular endothelial growth factor, and matrix metalloproteases in pancreatic cancer cell lines and xenografts. Cancer Biol Ther. 2010; 9:236-42.

49. Liuzzi JP, Bobo JA, Lichten LA, Samuelson DA, Cousins RJ. Responsive transporter genes within the murine intestinal-pancreatic axis form a basis of zinc homeostasis. Proc Natl Acad Sci USA. 2004; 101:14355-60.

50. Su LJ, Chang CW, Wu YC, Chen KC, Lin CJ, Liang SC, Lin $\mathrm{CH}$, Whang-Peng J, Hsu SL, Chen CH, Huang CY. Selection of DDX5 as a novel internal control for Q-RTPCR from microarray data using a block bootstrap resampling scheme. BMC Genomics. 2007; 8:140.

51. Hou J, Aerts J, den Hamer B, van Ijcken W, den Bakker M, Riegman P, van der Leest C, van der Spek P, Foekens JA, Hoogsteden HC, Grosveld F, Philipsen S. Gene expressionbased classification of non-small cell lung carcinomas and survival prediction. PLoS One. 2010; 5:e10312.

52. Landi MT, Dracheva T, Rotunno M, Figueroa JD, Liu H, Dasgupta A, Mann FE, Fukuoka J, Hames M, Bergen AW, Murphy SE, Yang P, Pesatori AC, et al. Gene expression signature of cigarette smoking and its role in lung adenocarcinoma development and survival. PLoS One. 2008; 3:e1651. 